\title{
Case Law of the Court of Justice of the European Union and the General Court
}

Reported Period 14.02.2019-01.07.2019

\author{
Lorenzo Squintani \\ University of Groningen \\ l.squintani@rug.nl
}

Overview of the Judgments ${ }^{1}$

1.1 On the Validity of the NEW NEC Directive

Judgment of the Court (Sixth Chamber) of 13 March 2019 in Case C/128/17 Poland $v$ Parliament and Council

\subsubsection{Subject Matter}

This case concerns an action for annulment against Directive (EU) 2016/2284, the New NEC Directive, brought by Poland and supported by Hungary and Romania. Poland alleged the infringement of several procedural and material norms by the establishing of the Directive. In particular Poland alleged the infringement of the duty to carry out a proper impact assessment and of the principle of sincere cooperation. It also alleged breach of the principles of proportionality and equal treatment. All plea were disbanded by the Court.

\subsubsection{Key Findings}

41 It follows from the foregoing considerations that the Republic of Poland is not entitled to claim that the data taken into account by the EU legislature in order to adopt the contested directive were incomplete as regards the individual situation of the Republic of Poland, since those data were compiled by IIASA jointly with representatives of that Member State and, in particular, on

1 Only opinions, judgements and orders available on Curia.eu under the subject matter 'environment' and 'provisions concerning the institutions/access to documents' have been included in this report. Due to the length constrains, only those proceedings that in the subjective opinion of the editor were considered interesting are included. 
the basis of data supplied by the latter. Moreover, as is apparent from Council Document No 11265/16 of 14 July 2016 (pages 66 and 67), the Republic of Poland did not forward all of the required information in respect of some of the pollutants covered by the contested directive.

42 For the same reasons and, in particular, since the EU legislature also relied on other information at its disposal, the Republic of Poland's argument that the impact assessment was vague, insufficient and overly general cannot succeed.

74 The duty of sincere cooperation cannot have a wider scope, in the sense of requiring the EU legislature, in all circumstances, to produce, at the request of a Member State, documents and information that are allegedly missing or to correct information available to it before being able to adopt an act. Such an interpretation could prevent the institutions from exercising their discretion and block the legislative process.

75 It is, admittedly, true that the duty of sincere cooperation includes the obligation of mutual assistance, which entails, among other things, the exchange of relevant information between the institutions and the Member States during the legislative process. However, that obligation cannot provide a means for one of those States, in the event of disagreement as to the adequacy, relevance or accuracy of the available data, to challenge the lawfulness of the decision-making process on that ground alone.

\subsection{On the Concept of Waste}

Judgment of the Court (First Chamber) of 14 March 2019 in Case C-399/17 Commission $v$ Czech Republic

\subsubsection{Subject Matter}

This infringement procedure against Czech Republic concerns this Member State failure to comply with Regulation (EC) No 1013/2006 on the shipment of waste (the Basel Regulation) when it refused to take-back to Czech Republic the shipment to Poland of Geobal which was deposited in Katowice (Poland) allegedly in breach of the Regulation. As the Basel Regulation only applies to the shipment of waste, it was first necessary to establish whether Geobal constitutes waste.

\subsubsection{Key Findings}

63 That point was confirmed, at the hearing before the Court, by the Czech Republic, which also acknowledged that the tar acid - the principal component of the mixture - was derived from former oil-refining activities on the Ostrava site and corresponds to 'waste tarry residues (excluding asphalt cements) 
arising from refining, distillation and any pyrolitic treatment of organic materials' in entry A319o in List A in Part 1 of Annex V to Regulation No 1013/2006. Nevertheless, that Member State submits that, by mixing it with carbon dust and calcium oxide to form TPS-NOLO (Geobal), that tar underwent a transformation which meant it ceased to be waste and was capable of being used as fuel in cement works.

73 It should be borne in mind, in that regard, that according to Article 2(2) of that regulation waste is not a substance, a mixture or article within the meaning of Article 3 of the regulation. It is true that, as the Commission submits, the mixture at issue may have been wrongly registered under the REACH Regulation in disregard of its classification as waste. However, such a hypothesis cannot be taken to demonstrate that the mixture is waste. While not permitting a definitive conclusion to the contrary, the registration of a substance under the REACH Regulation is, nevertheless, relevant for the purpose of determining whether that substance has ceased to be waste (see, to that effect, judgment of 7 March 2013, Lapin ELY-keskus, liikenne ja infrastruktuuri, C-358/11, EU:C:2013:142, paragraphs 63 and 64).

78 It follows from all the foregoing that the Commission cannot be considered to have proven to the requisite legal standard that the mixture at issue was waste within the meaning of Directive 2006/12. As a result, it has failed to establish that the shipment of that mixture from the Czech Republic to Poland in late 2010 or early 2011 constituted, at the time it took place, a shipment of waste within the meaning of Regulation No 1013/2006 and, as a result, that the Czech Republic failed to fulfil its obligations under Article 24(2) in conjunction with Article 28(1) of that Regulation. The Commission's action must therefore be dismissed.

\subsection{On the Duty to have a Permit for Operating Landfills}

Judgment of the Court (Fifth Chamber) of 21 March 2019 in Case C-498/17 Commission $v$ Italy

\subsubsection{Subject Matter}

This case concerns an infringement proceeding against Italy for breach of Directive 1999/31/EC on the landfill of waste (the Landfill Directive). Under the Directive, landfills which have been granted a permit or which were in operation before 16 July 2001 may not continue to operate after 16 July 2009 unless they obtained a permit in compliance with the Directive. Several Italian landfills did not comply with this obligation according to the Commission. The Court of Justice agrees with the Commission and condemns Italy for breach of the Directive. 


\subsubsection{Judgment}

Declares that, by having failed to adopt, with regard to the landfill sites of Avigliano (area of Serre Le Brecce), Ferrandina (area of Venita), Genzano di Lucania (area of Matinella), Latronico (area of Torre), Lauria (area of Carpineto), Maratea (area of Montescuro), Moliterno (area of Tempa La Guarella), both landfill sites of Potenza (area of Montegrosso-Pallareta), the landfill sites of Rapolla (area of Albero in Piano), Roccanova (area of Serre), Sant'Angelo Le Fratte (area of Farisi), Campotosto (area of Reperduso), Capistrello (area of Trasolero), Francavilla (Valle Anzuca), L'Aquila (area of Ponte delle Grotte), Andria (D’Oria G. \& C. Snc), Canosa (CO.BE.MA), Bisceglie (CO.GE.SER), Andria (F.lli Acquaviva), Trani (BAT-Igea Srl), Torviscosa (Caffaro (undertaking)), Atella (area of Cafaro), Corleto Perticara (area of Tempa Masone), Marsico Nuovo (area of Galaino), Matera (area of La Martella), Pescopagano (area of Domacchia), Rionero in Volture (area of Ventaruolo), Salandra (area of Piano del Governo), San Mauro Forte (area of Priati), Senise (area of Palomabara), Tito (area of Aia dei Monaci), Tito (area of Valle del Forno), Capestrano (area of Tirassegno), Castellalto (area of Colle Coccu), Castelvecchio Calvisio (area of Termine), Corfinio (area of Cannucce), Corfinio (area of Case querceto), Mosciano S. Angelo (area of Santa Assunta), S. Omero (area of Ficcadenti), Montecorvino Pugliano (area of Parapoti), San Bartolomeo in Galdo (area of Serra Pastore), Trivigano (formerly Cava Zof) and Torviscosa (area of La Valletta), all the measures necessary in order that, as soon as possible, in accordance with Article $7(\mathrm{~g})$ and Article 13 of Council Directive 1999/31/EC of 26 April 1999 on the landfill of waste, those landfill sites in the above list which have not obtained, in accordance with Article 8 of that directive, a permit to continue to operate, may be closed, or by failing to adopt the measures necessary to bring those landfill sites which have obtained a permit to continue to operate into line with that directive, without prejudice to the conditions laid down in Annex I, point 1, to that directive, the Italian Republic has failed to fulfil its obligations under Article 14(b) and (c) of Directive $1999 / 31$

\section{4}

On the Classification of a Substance as Waste or Hazardous Waste under the New Waste Directive

Judgment of the Court (Tenth Chamber) of 28 March 2019 in Joined Cases C-487/17 to C-489/17 - Verlezza and Others

\subsubsection{Subject Matter}

These requests for a preliminary ruling concern the interpretation of Article 4(2) of and Annex III to Directive 2008/98/EC on waste (the New Waste 
Directive) and Decision 2000/532/EC establishing a list of waste. The requests were made in criminal proceedings brought against Mr Alfonso Verlezza, and other natural and legal persons for offences concerning, inter alia, illegal waste trafficking. The waste in question is considered 'mirror' waste, thus waste that can be classified as 'waste' or as 'hazardous waste' under Annex III of the New Waste Directive and the Annex to Decisions 200o/532/EC. The Supreme Court of Cassation, Italy had doubts about how to classify the waste at hand in the proceedings and as to whether the precautionary principle dictates a specific choice between these two regimes in case of uncertainty. Accordingly, it asked for a preliminary reference to the Court of Justice.

\subsubsection{Key Findings}

40 Therefore, where the composition of waste to which mirror codes may be assigned is not immediately known, it falls to the holder of that waste, as the party responsible for its management, to gather information which may enable it to gain sufficient knowledge of that composition and, thus, assign the appropriate code to that waste.

62 In view of those considerations, the answer to the fourth question is that the precautionary principle must be interpreted to the effect that where, following an assessment of the risks, which is as complete as possible having regard to the particular circumstances of the case, it is impossible, in practical terms, for a holder of waste which may be classified under mirror codes to determine the presence of hazardous substances or to assess the hazardous property of that waste, it must be classified as hazardous waste.

\subsection{On the Criteria for the End-of-Waste Status under the New Waste Directive}

Judgment of the Court (Second Chamber) of 28 March 2019 in Case C-6o/18 Tallinna Vesi

\subsubsection{Subject Matter}

This request for a preliminary ruling concerns the interpretation of Article 6(4) of the New Waste Directive. The request has been made in the proceedings between Tallinna Vesi AS and Keskkonnaamet (Environmental Board, Estonia), concerning the adoption of two notices by the latter which were issued to Tallinna Vesi in relation to the recovery of waste and which refused to recognise end-of-waste status for sewage sludge that had undergone recovery treatment. Under Estonian law, where criteria have not been set at EU level for determining end-of-waste status as regards a specific type of waste, such end status depends on the existence of criteria laid down in a generally applicable national 
legal act concerning that type of waste. As nor EU law, nor national law establish such criteria for sewage sludge that has undergone recovery treatment, Tallinna Vesi's requests was refuted. The Court of Appeal, Tallinn, Estonia, asked, in essence, whether this is allowed under the Directive and whether Tallinna Vesi may demand the recognition of the end-of-waste status by Estonia.

\subsubsection{Key Findings}

25 Article 6(4) of Directive 2008/98 does not, therefore, preclude national legislation under which, where no criteria are laid down at EU level for determining end-of-waste status as regards a specific type of waste, the end of that status of waste depends on the existence of criteria laid down in a generally applicable national legal act concerning that type of waste.

30 Consequently, it must be held that Article 6(4) of Directive 2008/98 does not allow a waste holder, such as Tallinna Vesi, to demand, in circumstances such as those in the main proceedings, the recognition of end-of-waste status by the competent authority of the Member State or by a court of that Member State.

\subsection{On the Relationship between EU Law and Investment Law}

Opinion of the Court (Full Court) of 30 April 2019 in Opinion 1/17 - EU-Canada cET Agreement

\subsubsection{Subject Matter}

This opinion concerns the agreement signed in Brussels on 30 October 2016 between Canada, of the one part, and the European Union and its Member States, of the other part, about a 'Comprehensive Economic and Trade Agreement', better known by the acronym 'CETA'. In its request for an opinion, the Kingdom of Belgium makes known to the Court its doubts as to whether Section F of Chapter 8 of the CETA is compatible with the Treaties. The purpose of Section F of Chapter 8 of the CETA is to establish a mechanism for the resolution of disputes between investors and States, also known as the Investor-State Dispute Settlement system (ISDS). To that end, that section provides for the establishment of a Tribunal ('the Tribunal' or 'the CETA Tribunal') and an Appellate Tribunal ('the Appellate Tribunal' or the 'the CEtA Appellate Tribunal') as well as, in the longer term, a multilateral investment tribunal and appellate mechanism which would bring to an end the functioning of the initial tribunals. CETA thus provides for an institutionalised procedural framework with the aim of settling any disputes between an investor of one Party and the other Party concerning the interpretation and application of the CETA, which 
is intended to remedy the shortcomings ascribed to the classical ISDS system. An important aspect of the case concerned the relationship between CETA and EU law from the perspective of the EU autonomy principle.

\subsubsection{Key Findings}

119 Consequently, in order to determine the compatibility of the envisaged ISDS mechanism with the autonomy of the EU legal order, it is necessary to be satisfied that:

- Section F of Chapter Eight of the CETA does not confer on the envisaged tribunals any power to interpret or apply EU law other than the power to interpret and apply the provisions of that agreement having regard to the rules and principles of international law applicable between the Parties, and

- Section F of Chapter Eight of the CETA does not structure the powers of those tribunals in such a way that, while not themselves engaging in the interpretation or application of rules of EU law other than those of that agreement, they may issue awards which have the effect of preventing the EU institutions from operating in accordance with the EU constitutional framework.

134 Since the CETA Tribunal and Appellate Tribunal stand outside the EU judicial system and since their powers of interpretation are confined to the provisions of the CETA in the light of the rules and principles of international law applicable between the Parties, it is, moreover, consistent that the CETA makes no provision for the prior involvement of the Court that would permit or oblige that Tribunal or Appellate Tribunal to make a reference for a preliminary ruling to the Court.

135 For the same reasons, it is, moreover, consistent that the CETA confers on those Tribunals the power to give a definitive ruling on a dispute brought by an investor against the investment host State or against the Union, without establishing any procedure for the re-examination of the award by a court of that State or by the Court and without that investor being permitted - subject to the specific exceptions listed in Article 8.22.5 of the CETA - to bring, during or on the conclusion of the procedure before those Tribunals, the same dispute before a court of that State or before the Court.

${ }_{13} 6$ It follows from the foregoing that Section F of Chapter Eight of the CETA does not confer on the envisaged tribunals any jurisdiction to interpret or apply EU law other than that relating to the provisions of that agreement. 
245 It follows from all the foregoing that Section $\mathrm{F}$ of Chapter Eight of the CETA is compatible with EU primary law.

1.7 On the Right to Access toJustice in Environmental Matters at EU Level Order of the General Court (Second Chamber) of 8 May 2019 in Case T-330/ 18 - Carvalho and Others $v$ Parliament and Council

\subsubsection{Subject Matter}

The proceeding concerns an action for annulment brought by private parties before the General Court. The applicants, Mr Armando Carvalho and the other natural and legal persons seek the annulment in part of Directive (EU) 2018/410 amending Directive 2003/87/EC to enhance cost-effective emission reductions and low-carbon investments, Regulation (EU) 2018/842 on binding annual greenhouse gas emission reductions by Member States from 2021 to 2030 contributing, and Regulation (EU) 2018/841 on the inclusion of greenhouse gas emissions and removals from land use, land use change and forestry in the 2030 climate and energy framework. Moreover, they seek compensation under Articles 268 and 340 TFEU in the form of an injunction for the damage that the applicants claim to have suffered.

\subsubsection{Key Findings}

47 Such an argument cannot succeed.

48 It is apparent from the case-law that, although it is true that, when adopting an act of general application, the institutions of the Union are required to respect higher-ranking rules of law, including fundamental rights, the claim that such an act infringes those rules or rights is not sufficient in itself to establish that the action brought by an individual is admissible, without running the risk of rendering the requirements of the fourth paragraph of Article 263 TFEU meaningless, as long as that alleged infringement does not distinguish the applicant individually just as in the case of the addressee (see judgment of 2 March 2010, Arcelor v Parliament and Council, T-16/04, EU:T:2010:54, paragraph 103 and the case-law cited).

49 The applicants have not established that the contested provisions of the legislative package infringed their fundamental rights and distinguished them individually from all other natural or legal persons concerned by those provisions just as in the case of the addressee.

66 That principle is limited by the prohibition on abuse of the proceedings. An applicant may not, by means of an action for damages, attempt to obtain a result similar to the result of annulling the act, where an action for annulment 
concerning that act would be inadmissible (see, to that effect, judgment of 15 December 1966, Schreckenberg v Commission, 59/65, EU:C:1966:6o, p. 797).

\subsection{On Compliance with the 'Waste of Hierarchy' Principle and the SEA Directive}

Judgment of the Court (Sixth Chamber) of 8 May 2019 in Case C-305/18 - "Verdi Ambiente e Società - Aps Onulu" and Others

\subsubsection{Subject Matter}

This request for a preliminary ruling concerns the interpretation of Directive 2001/42/EC on the assessment of the effects of certain plans and programmes on the environment (the SEA Directive) and the New Waste Directive. The request has been made in the context of proceedings between, on the one hand, the environmental protection organisations Verdi Ambiente e Società (VAS) and Others and, on the other hand, the Presidenza del Consiglio dei Ministri (Presidency of the Council of Ministers, Italy) and Others concerning an action seeking the annulment of a decree of the President of the Council of Ministers on the identification of the overall treatment capacity of facilities for the incineration of municipal and similar waste. The Regional Administrative Court of Lazio, Italy, asked to the Court of Justice, in essence, whether the 'waste hierarchy' principle must be interpreted as precluding national legislation, such as that at issue in the main proceedings, which classifies waste incineration facilities as 'strategic infrastructure and installations of major national importance'. Moreover, it asked whether the SEA Directive must be interpreted as meaning that national legislation, such as that at issue in the main proceedings, comprising basic legislation and implementing legislation, which revises upwards the capacity of existing waste incineration facilities and which provides for the construction of new installations of that kind, comes under the notion of 'plans and programmes', within the meaning of that directive, and which must, consequently, be subject to a prior environmental assessment.

\subsubsection{Key Findings}

31 Moreover, according to Article 13 of the 'Waste' Directive, Member States take the necessary measures to ensure that waste management is carried out without endangering human health and without harming the environment, in particular without risk to water, air, soil, plants or animals.

33 In the present case, the fact that national legislation, such as that at issue in the main proceedings, classifies waste incineration facilities as 'strategic infrastructure and installations of major national importance' does not mean 
that the national legislature intended to disregard the instructions stemming from the 'waste hierarchy' principle, as provided for in the 'Waste' Directive. 60 It follows that the answer to the third question is that Article 2(a), Article 3(1), and Article 3(2)(a) of the sEA Directive must be interpreted as meaning that national legislation, such as that at issue in the main proceedings, comprising basic legislation and implementing legislation, which revises upwards the capacity of existing waste incineration facilities and which provides for the construction of new installations of that kind, comes under the notion of 'plans and programmes', within the meaning of that directive, where it is likely to have significant environmental effects and must, consequently, be subject to a prior environmental assessment.

\subsection{On the Concept of Waste Exempted from the Basel Regulation Requirements I}

Judgment of the Court (Fifth Chamber) of 16 May 2019 in Case C-689/17 - Conti 11. Container Schiffahrt

\subsubsection{Subject Matter}

This request for a preliminary ruling concerns the interpretation of Article 1(3) (b) of Basel Regulation. The request has been made in proceedings between 'Conti 11. Container Schiffahrts-GmbH \& Co. KG Ms 'MSc Flaminia' ('Conti') and Land Niedersachsen (the Land of Lower Saxony, Germany) concerning the obligation imposed by the latter on Conti to carry out a notification procedure relating to shipment of waste that was on board the ship MSC Flaminia ('the Flaminia') following damage at sea. The Regional Court of Munich I, Germany, asked to the Court of Justice, in essence, whether residues in the form of scrap metal and of fire-extinguishing water mixed with sludge and cargo residues, such as those at issue in the main proceedings, attributable to damage occurring on board a ship at sea, must be regarded as waste generated on board ships, within the meaning of the Regulation.

\subsubsection{Key Findings}

53 It follows from the foregoing considerations that Article 1(3)(b) of Regulation No 1013/2006 must be interpreted as meaning that residues, in the form of scrap metal and of fire-extinguishing water mixed with sludge and cargo residues, such as those at issue in the main proceedings, attributable to damage occurring on board a ship at sea, must be regarded as waste generated on board ships, within the meaning of that provision, which is, therefore, excluded from that regulation's scope until it is offloaded in order to be recovered or disposed of. 


\subsection{On the Concept of Waste Exempted from the Basel Regulation Requirements II}

Judgment of the Court (Fifth Chamber) of 23 May 2019 in Case C-634/ $17-$ ReFood

\subsubsection{Subject Matter}

This request for a preliminary ruling concerns the interpretation of Articles $1(3)(d)$ of the Basel Regulation. The request has been made in proceedings between ReFood GmbH \& Co. KG ('ReFood') and the Landwirtschaftskammer Niedersachsen (Lower Saxony Chamber of Agriculture, Germany) concerning the legality of a transfer of animal by-products from the Netherlands to Germany. The Administrative Court of Oldenburg, Germany, asked to the Court of Justice, in essence, whether all shipments of animal by-products covered by Regulation No 1069/2009 laying down health rules concerning animal byproducts not intended for human consumption or only certain of those shipments, which satisfy specific conditions imposed by Regulation No 1069/2009, are excluded from the scope of the Basel Regulation, under Article 1(3)(d) of that regulation.

\subsubsection{Key Findings}

$5^{1}$ Thus, as regards the transport of category 3 animal by-products from one Member State to another, in addition to the general obligations concerning the traceability of animal by-products and the registration of operators provided for in Articles 22 and 23, Regulation No 1069/2009 is, in essence, limited to providing, in Article 21(2), that operators shall ensure that a commercial document or, in certain cases, a health certificate accompanies such by-products during their transport. It adds, in Article 21(4), that operators shall carry out the transport of category 3 culinary waste in accordance with the national measures provided for in Article 13 of Directive 2008/98, which provides that Member States shall take the necessary measures to ensure that waste management is carried out without endangering human health and harming the environment.

$5^{2}$ In contrast, as regards category 1 or 2 materials and certain products derived from those materials, Article 48(1) of Regulation No 1069/2009 provides that the dispatch from one Member State to another is subject to consent by competent authority of the Member State of destination.

62 Having regard to all of the foregoing considerations, the answer to the questions referred is that Article $1(3)(d)$ of Regulation No 1013/2006 must be interpreted as meaning that shipments of animal by-products falling within Regulation No 1069/2009 are excluded from the scope of Regulation No 1013/2006, 
except in cases where Regulation No 1069/2009 expressly provides for the application of Regulation No 1013/2006.

\subsection{On the Relationship between the Habitats Directive and the SEA Directive I}

Judgment of the Court (First Chamber) of 12 June 2019 in Case C-321/18 - Terre wallonne

\subsubsection{Subject Matter}

This request for a preliminary ruling concerns the interpretation of Article 3(2) and (4) of the SEA Directive. The request was made in the course of proceedings between Terre Wallonne ASBL and Région wallonne (Walloon Region, Belgium) concerning the validity of the Walloon Government's Decree of 1 December 2016 setting conservation objectives for the Natura 2000 network. The Council of State, Belgium, asked to the Court of Justice, in essence, whether Article 3(2) and (4) of the SEA Directive must be interpreted as meaning that a decree, such as that at issue in the main proceedings, by which a body of a Member State establishes conservation objectives at regional level for its $\mathrm{Na}-$ tura 2000 network, is one of the 'plans and programmes' for which an environmental impact assessment is mandatory.

\subsubsection{Key Findings}

42 In the present case, the Decree of 1 December 2016 does not set out conservation objectives for specific sites, but summarises them for the Walloon region as a whole. Furthermore, it is apparent from the third subparagraph of Article $25 \mathrm{a}(1)$ of the Law of 12 July 1973 that the conservation objectives at Walloon Region level have indicative value only, whereas the second subparagraph of Article $25 \mathrm{a}(2)$ provides that the conservation objectives applicable at the level of Natura 2000 sites have statutory value.

43 In the light of those factors, it must be held that a measure, such as that at issue in the main proceedings, fails to satisfy the condition recalled in paragraph 41 of the present judgment, in that it does not set a framework for future development consent of projects, with the effect that it does not come within the scope either of Article 3(2)(a) or Article 3(4) of the SEA Directive.

44 In the light of the foregoing, the answer to the questions referred is that Article 3(2) and (4) of the SEA Directive must be interpreted as meaning that a decree, such as that at issue in the main proceedings, by which a body of a Member State establishes, at regional level for its Natura 2000 network, conservation objectives which have an indicative value, whereas the conservation 
objectives at site level have a statutory value, is not one of the 'plans and programmes', within the meaning of that directive, for which an environmental impact assessment is mandatory.

\subsection{On the Relationship between the Habitats Directive and the SEA Directive II}

Judgment of the Court (First Chamber) of 12 June 2019 in Case C-43/18 Compagnie d'entreprises CFE

\subsubsection{Subject Matter}

This request for a preliminary ruling concerns the interpretation of Article $3(2)$, (4) and (5) of the SEA Directive. The request has been made in proceedings between Compagnie d'entreprises CFE SA ('CFE') and Région de Bruxelles-Capitale (Brussels-Capital Region, Belgium), concerning the validity of the decree of 14 April 2016 of the Government of that region designating Natura 2000 site BE1000001 'La Forêt de Soignes avec lisières et domaines boisés avoisinants et la Vallée de la Woluwe' ('The Sonian forest together with forest margins and surrounding wooded areas and the Woluwe valley'). The Council of State, Belgium, asked to the Court of Justice, in essence, whether Article 3(2) and (4) of the SEA Directive is to be interpreted as meaning that a decree such as that at issue in the main proceedings, whereby a Member State designates a Special Area of Conservation and makes provisions as to conservation objectives and certain preventive measures, is one of the 'plans and programmes' in respect of which an environmental impact assessment is required.

1.12.2 Judgment

Article 3(2) and (4) of Directive 2001/42/EC of the European Parliament and of the Council of 27 June 2001 on the assessment of the effects of certain plans and programmes on the environment is to be interpreted, subject to those matters which are for the referring court to verify, as meaning that a decree such as that at issue in the main proceedings, whereby a Member State designates an SAC, and makes provision as to conservation objectives and certain preventive measures, is not among the 'plans and programmes' in respect of which an environmental impact assessment is required.

\subsection{On the Free Allocation of Allowances and the Concept of Electricity Generator under the ETS Directive Framework}

Judgment of the Court (First Chamber) of 20 June 2019 in Case C-682/17 ExxonMobil Production Deutschland 


\subsubsection{Subject Matter}

This request for a preliminary ruling concerns the interpretation of Article $3(\mathrm{u})$ and Article 10a of, and Annex I to, Directive 2003/87/EC establishing a scheme for greenhouse gas emission allowance trading (the ETs Directive), and of Article $3(\mathrm{c})$ and $(\mathrm{h})$ of Commission Decision 2011/278/EU determining transitional Union-wide rules for harmonised free allocation of emission allowances. The request has been made in proceedings between ExxonMobil Production Deutschland GmbH ('ExxonMobil') and Bundesrepublik Deutschland (the Federal Republic of Germany) concerning an application for the allocation of greenhouse gas emission allowances ('emission allowances') free of charge to a natural gas processing installation which carries out, inter alia, sulphur recovery, in the course of which, by combustion of fuels, it generates electricity and heat, releasing carbon dioxide $\left(\mathrm{CO}^{2}\right)$ into the atmosphere. The Administrative Court of Berline, Germany, asked to the Court of Justice, in essence, whether and, if so, to what extent, an installation, such as the installation at issue, which engages in natural gas desulphurisation and sulphur recovery under the Claus process, is entitled to be allocated emission allowances free of charge for the $\mathrm{CO}^{2}$ emitted in the course of those activities in respect of the trading period running from 2013 to 2020.

\subsubsection{Key Findings}

92 As follows from paragraph $5^{8}$ of the present judgment, an installation such as the installation at issue in the main proceedings falls within the scope of Directive 2003/87 only in respect of the $\mathrm{CO}_{2}$ emissions resulting from such an activity of combustion of fuels. Therefore, it is subject to the emission allowance trading scheme only in respect of that activity, to the exclusion of other activities not falling within Annex I to the directive. On the other hand, an installation carrying out simultaneously an activity of combustion of fuels and one or more other activities referred to in Annex I is subject to that trading scheme in respect of all of its activities that produce $\mathrm{CO}_{2}$ emissions. Accordingly, even though those two types of installation produce electricity, an installation of the second type, which falls within the trading scheme in respect of all its $\mathrm{CO}_{2}$ emissions resulting from such activities, is entitled to obtain free allowances in respect of those emissions, unlike an installation of the first type which, since it is subject to the trading scheme only in respect of its $\mathrm{CO}_{2}$ emissions resulting from the activity of combustion of fuels, does not qualify for such allowances.

96 Consequently, the answer to the first question is that Article $3(\mathrm{u})$ of Directive 2003/87 must be interpreted as meaning that an installation, such as that 
at issue in the main proceedings, which produces, within the framework of its activity of 'combustion of fuels in installations with a total rated thermal input exceeding $20 \mathrm{MW}$ ', referred to in Annex I to that directive, electricity intended essentially to be used for its own needs, must be regarded as an 'electricity generator', within the meaning of that provision, where that installation, first, carries out simultaneously an activity for producing a product which does not fall within that annex and, second, continuously feeds, for consideration, even a small part of the electricity produced into the public electricity network, to which that installation must be permanently connected for technical reasons. 124 It follows from all the foregoing that, where an installation such as that in the main proceedings must be regarded as an 'electricity generator', within the meaning of Article 3(u) of Directive 2003/87, it cannot be allocated free emission allowances under Article 10a of that directive and the provisions of Decision 2011/278.

\subsection{On the Assessment of Ambient Air Quality under the Air Quality Directive}

Judgment of the Court (First Chamber) of 26 June 2019 in Case C-723/17 Craeynest and Others

\subsubsection{Subject Matter}

This request for a preliminary ruling concerns the interpretation of, most importantly, Article 4(3) TEU and Articles 6, 7, 13 and 23 of and Annexes III and XI to Directive 2008/50/EC on ambient air quality and cleaner air for Europe (the Air Quality Directive). The request has been made in the context of a dispute between Ms Lies Craeynest and other, on the one hand, and the Brussels Hoofdstedelijk Gewest (Brussels Capital Region, Belgium) and the Brussels Instituut voor Milieubeheer (Brussels Institute for Environmental Management, Belgium), on the other, regarding the obligation to develop an air quality plan for the Brussels zone (Belgium) and to install the sampling points legally required to monitor air quality. Most importantly, the Dutch-language Court of First Instance, Brussels, Belgium, asked to the Court of Justice, in essence, whether Article 13(1) and Article 23(1) of Directive 2008/50 must be interpreted as meaning that, in order to establish whether a limit value with an averaging period of one calendar year, as laid down in Annex XI to that Directive, has been exceeded, it is sufficient that a pollution level higher than that value be measured at a single sampling point or whether it is necessary that the average of the measurements taken at all the sampling points in a particular zone or agglomeration indicate such a pollution level. 


\subsubsection{Key Findings}

$5^{6}$ In view of all the above considerations, the answer to the first question is that Article 4(3) TEU and the second subparagraph of Article 19(1) TEU, read in conjunction with the third paragraph of Article $288 \mathrm{TFEU}$, and Articles 6 and 7 of Directive 2008/50 must be interpreted as meaning that it is for a national court, hearing an application submitted for that purpose by individuals directly affected by the exceedance of the limit values referred to in Article 13(1) of that directive, to verify whether the sampling points located in a particular zone have been established in accordance with the criteria laid down in paragraph 1(a) of Section B of Annex III to the directive and, if they were not, to take all necessary measures in respect of the competent national authority, such as, if provided for by national law, an order, with a view to ensuring that those sampling points are sited in accordance with those criteria.

59 As the Advocate General noted in points 72 to 75 of her Opinion, the wording of Article 13(1) of Directive 2008/50 does not make it possible to answer the second question raised by the referring court. The same applies as regards Article 23(1) of that directive.

60 When a literal interpretation of a provision of EU law does not permit its precise scope to be assessed, it must be interpreted by reference to the general scheme and the purpose of the rules of which it forms part (judgment of 6 June 2018, Koppers Denmark, C-49/17, EU:C:2018:395, paragraph 22 and the case-law cited).

61 It follows from Article 6(1) and the third subparagraph of Article 13(1) of Directive 2008/50 that it is for the Member States to assess compliance with the limit values in accordance with the requirements and criteria set out in Annex III to that directive. As is apparent from paragraph 1 of Section A of that annex, Sections B and C of that annex concern the location of sampling points, but also provide guidance for the implementation of the other air quality assessment methods provided for in Directive 2008/50.

62 In this respect, it was observed, in paragraph 39 above, that the provisions of paragraph 1(a) and (f) of Section B of Annex III to Directive 2008/50 require sampling points to provide representative data for locations in a zone or agglomeration characterised by a certain level of pollution. The system thus designed by the EU legislature seeks to enable the competent authorities not only to know the level of air pollution at the location represented by a sampling point, but also to infer from this the level of pollution at other similar locations. As is apparent from recital 14 of Directive 2008/50, the latter objective is achieved, inter alia, by using modelling techniques.

63 It follows that the determination of the average of the values measured at all sampling points in a zone or agglomeration does not provide a valid 
indication as to the population's exposure to pollutants. In particular, such an average does not make it possible to determine the level of exposure of the population in general, since that level must be assessed using sampling points set up specifically for that purpose, in accordance with the second indent of paragraph 1(a) of Section B of Annex III to Directive 2008/50.

68 In view of all the above considerations, the answer to the second question is that Article 13(1) and Article 23(1) of Directive 2008/50 must be interpreted as meaning that, in order to establish whether a limit value with an averaging period of one calendar year, as laid down in Annex XI to that directive, has been exceeded, it is sufficient that a pollution level higher than that value be measured at a single sampling point.

\section{Editor's Appraisal of the Reported Case Law}

The reported period was a relatively long one. Within the limited space available for this appraisal, I will highlight two main elements emerging from the reported case law, both of which place questions on the ability of EU environmental law to move forward on key issues: a) the uncertainty about the concept of waste, and b) the reluctance of the Court of Justice to loosen-up its control on EU law.

The readers of this appraisal surely noticed the many cases about waste management reported here. Despite the abundant case law and literature existing on this topic, including in this journal, ${ }^{2}$ undertakings, national authorities and even the European Commission still do not know precisely when something is waste or not, at least not in all cases. Besides when something clearly is waste, they still do not always know what kind of waste it is. The Commission $v$ Czech Republic case (C-399/17) about the classification of Geobal, is emblematic in this regard. Most of the Commission's arguments to establish whether Geobal is waste or not were rejected by the Court of Justice. What the proceedings bring forward is not only the uncertainty about whether the

2 Most notably, T. Turunen, Deconstructing the Bottlenecks Caused by Waste Legislation: Endof-Waste Regulation, JEEPL (2017) 14(2):186-207; N. de Sadeleer, Scrap Metal Intended for Metal Production: The Thin Line between Waste and Products, JEE PL (2012) 9(2), pp. 136-163, at p. 140; I. Cheyne, Taming the Precautionary Principle in EC Law: Lessons from Waste and GMO Regulation, JEEPL (2007) 4(6), pp. 468-483, at pp. 471-472; M. Reese \& H-J Koch, Revising the Waste Framework Directive Basic Deficiencies of European Waste Law and Proposals for Reform, JEEPL (2005) 6(2): 441-457; N. de Sadeleer, EC Waste Law or How to Juggle with Legal Concepts, JEEPL (2005) 6(2): 458-477; and N. de Sadeleer, New Perspectives on the Definition of Waste in EC Law; JEEPL (2005) 2(1): 46-58. 
findings of an evaluation process on the nature of a product support concluding whether that product is waste or not. It is the very methodology used in this regard that was at times criticised by the Court. This case, when considered together with those in Conti (C-689/17), ReFood (C-634/17) and Tallinna Vesi (C-6o/18), suggests the possible existence of a pattern in which authorities prefer to play 'on the safe side' and impose the strictest regime possible among those available in case of uncertainty. In Conti and ReFood, national authorities had opted for the strictest regime available about the shipment of waste and in Tallina Vesi for a restrictive regime about the granting of the end-of-waste status. It would be interesting to research whether a possible tendency to play on the safe side emerging from the reported cases is a mere coincidence or it actually derives from a preference embedded in the EU waste law system. Verlezza and Others (C-489/17) seems to support the latter hypothesis as in this case the Court of Justice established that in case of uncertainty about whether a waste substance should be considered waste or hazardous waste, the precautionary principle dictates that public authorities opt for the most stringent classification, the hazardous waste one. This preference is perfectly understandable from the perspective of the principles guiding EU environmental law under Article $191 \mathrm{TFEU}$. However, it would be interesting to shade light about the effects that the circular economy movement - with its interest in bringing waste into the production phase - has on the meaning of these principles in the field of waste law. Studies on the concepts of 'waste', 'by products' and 'end-of-waste' status are thus very welcome. ${ }^{3}$ A case in this appraisal, Tallina Vesi, shows that the Court of Justice is willing to recognise some freedom to the Member States about whether to grant, and under which conditions, the end-of-waste status. The review of Estonian's choices in this regard was quite lenient by the Court. This suggests that Member States can adopt different regimes, pursuing different levels of protection, therefore engaging in green-plating. However, Member States do not have carte blanche in this regard. ${ }^{4}$ In particular, it would be interesting to see whether a more stringent approach will be followed in case a party relies on the EU free movement provisions. All in all, it can be expected that waste law will still be subject of many proceedings aiming at clarifying its meaning. Fifty-five years of case law have not been enough.

The other enduring trend highlighted in this appraisal concerns the reluctance of the Court of Justice to loosen-up its control on EU law. Two

3 See in particular, T. Turunen, The concepts of waste and non-waste in the circular economy, University of Eastern Finland. Dissertations (2018).

4 L. Squintani, Beyond Minimum Harmonisation: Gold-Plating and Green-Plating of European Environmental Law, Cambridge University Press (2019), in particular, 116-166. 
proceedings in this appraisal confirm this trend. Firstly, Opinion $1 / 17$ about the validity of the Investor-State Dispute Settlement (ISDS) system under the CETA clears the agreement, but poses severe restrictions on the scope of the review that can be performed by the CETA tribunals. In short, as soon as EU law is to be discussed in a proceeding, competence is reserved to the Court of Justice. It is to be seen how this limitation will affect the functioning of the tribunals. Surely, when this opinion is coupled with the Achmea case (C-284/16), concerning agreements between Member States rather than between Member States and third countries, it is clear that the Court of Justice is reluctant torelinquish its control on EU law. This could create frictions between EU law and international investment law the consequences of which are yet to be seen. An upcoming article of Fermanglia and Mistura in the next volume of this journal is therefore a welcome first step in shading light on this topic. $^{5}$

The other proceedings which surely did not escape the attention of the reader of this appraisal is the order of the General Court in Carvhalo (T-330/18). Inspired by the Urgenda first and second instance judgments, ${ }^{6}$ this proceedings aims at opening locus standi before the Court of Justice in environmental matters. This is a heightened topic which saw the publication of different positions in this very journal. ${ }^{7}$ It would be interesting to understand whether the choice of handling this case by order rather than by judgment shows a lack of willingness from the General Court to give this topic the attention it deserves. More interesting, however, is how the Court of Justice will handle the appeal case launched in the meanwhile. Surly, the Court has a new opportunity to move forward on this topic, which is an achievement in itself for which the applicants can be congratulated.

5 For a prior to Achmea and Opinoin 1/17 assessment, see L. Ankersmit, The Compatibility of Investment Arbitration in EU Trade Agreements with the eu Judicial System, JEEPL (2016) 13(1): 46-63.

6 Eg. B.W. Wegener, Urgenda - World Rescue by Court Order? The "Climate Justice"-Movement Tests the Limits of Legal Protection, JEEPL (2019) 16(2): 125-147.

7 Eg. Weener, op. cit.; and Matthijs van Wolferen, Case C-243/15 Lesoochranárske zoskupenie vlk v Obvodný úrad Trenčín, JEEPL (2017) 14(1): 136-151. 